\title{
INKLUSI KEUANGAN DAN LITERASI KEUANGAN TERHADAP KINERJA DAN KEBERLANGSUNGAN SEKTOR USAHA MIKRO KECIL MENENGAH
}

\author{
Mei Ruli Ninin Hilmawati \\ Fakultas Ekonomi, Universitas Negeri Surabaya \\ meihilmawati16080694035@mhs.unesa.ac.id \\ Rohmawati Kusumaningtias \\ Fakultas Ekonomi, Universitas Negeri Surabaya \\ rohmawatikusumaningtias@unesa.ac.id
}

\begin{abstract}
Abstrak: Inklusi Keuangan dan Literasi Keuangan terhadap Kinerja dan Keberlangsungan Sektor Usaha Mikro Kecil Menengah. Suatu kinerja unggul dan bisnis yang berkelanjutkan dapat terwujud apabila terdapat upaya-upaya strategis yang dilakukan. Jawa Timur merupakan salah satu provinsi dengan jumlah UMKM yang cukup banyak memiliki peluang yang besar untuk meningkatkan perekonomian Indonesia. Penelitian ini dilakukan untuk menganalisis pengaruh inklusi keuangan dan literasi keuangan terhadap kinerja dan keberlangsungan sektor UMKM yang terdapat di Kota Surabaya. Penelitian ini merupakan penelitian kuantitatif dengan inklusi keuangan (INKA) dan literasi keuangan (LIKA) sebagai variabel independen, serta kinerja usaha (KIUS) dan keberlangsungan usaha (KEUS) sebagai variabel dependen. Sampel pada penelitian ini berjumlah 113 UMKM yang kemudian dilakukan analisis dengan pendekatan Partial Least Square. Hasil penelitian menyimpulkan bahwa inklusi keuangan tidak berpengaruh terhadap kinerja dan keberlangsungan sektor UMKM. Sedangkan literasi keuangan memiliki pengaruh yang terhadap kinerja dan keberlangsungan sektor UMKM.
\end{abstract}

Kata kunci: Inklusi Keuangan, Literasi Keuangan, Kinerja Bisnis, Keberlangsungan Bisnis, UMKM

Abstract: Financial Inclusion and Financial Literacy on the Performance an Sustainability of the MSMEs. Excellent performance and sustainable business can be realized if there are strategic efforts. East Java, as one of the Province with a large number of MSMEs that have a great opportunity to improve the Indonesian economy. This study was conducted to analyze the effect of financial inclusion and financial literacy on the performance and sustainability of MSMEs in Surabaya. This research is a quantitative study with independent variables are financial inclusion (INKA) and financial literacy (LIKA), and the dependent variables are business performance (KIUS) and business continuity (KEUS). The sample in this study amounted to 113 MSMEs which were then analyzed using the Partial Least Square approach. this study concludes that financial inclusion has no effect on the performance and sustainability of MSMEs. while financial literacy has a influence on the performance and sustainability of MSMEs.

Keywords: Financial Inclusion, Financial Literacy, Business Performance, Sustainability, MSMEs

\section{PENDAHULUAN}

Indonesia merupakan salah satu negara yang memiliki populasi terbanyak setelah China, India, dan Amerika Serikat (Factbook, 2020). Jumlah penduduk yang padat membuat Indonesia dihadapkan dengan beberapa problematika diantaranya adalah masalah pengangguran dan kemiskinan (Badan Kebijakan Fiskal, n.d.).

Salah satu sektor yang berperan besar dalam mengurangi tingkat pengangguran dan kemiskinan di Indonesia adalah sektor UMKM. Usaha Mikro Kecil Menengah menyerap tenaga kerja sekitar $97 \%$ dari 


\section{Nominal: Barometer Riset Akuntansi dan Manajemen}

P-ISSN: 2303-2065 E-ISSN: 2502-5430

Volume 10 No 1 (2021)

seluruh tenaga kerja Indonesia dan meberikan kontribusi sebesar $60 \%$ terhadap Produk Domestik Bruto (Bank Indonesia, 2015). Namun, kemampuan akses pembiayaan oleh UMKM hanya sebesar $30 \%$ dari total 56,54 juta UMKM yang tersebar di seluruh Indonesia (Bank Indonesia, 2015). Hasil Survei Nasional Literasi dan Inklusi Keuangan tahun 2013 dan 2016 oleh OJK menunjukkan bahwa indeks inklusi keuangan lebih tinggi dari indeks literasi keuangan (OJK-RI, 2017).

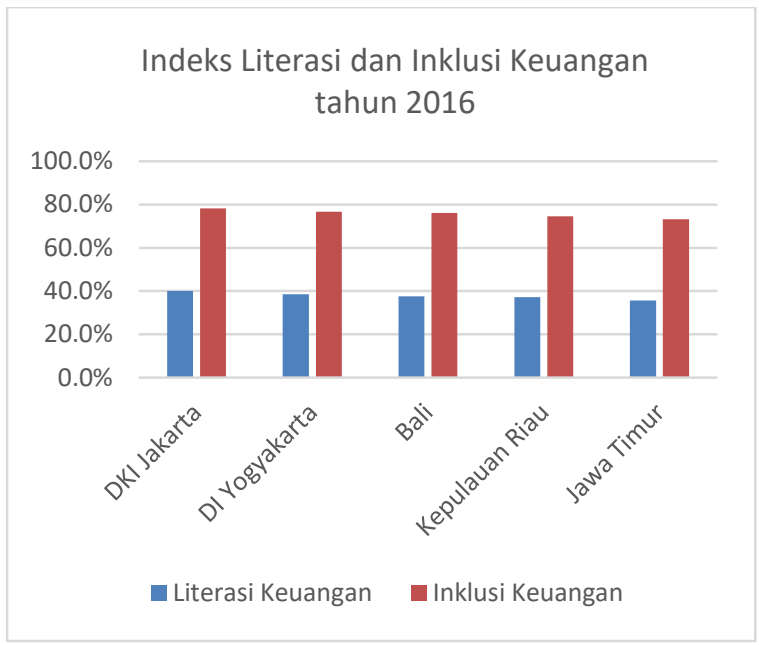

Sumber: Data Dioleh SNLKI (revisi 2017)

Gambar 1: Indeks Literasi dan Inklusi Keuangan beberapa Provinsi di Indonesia

Pemahaman serta pengetahuan mengenai inklusi dan literasi keuangan sangat penting dimiliki oleh pelaku UMKM. Hal tersebut dikarenakan inklusi dan literasi keuangan berpengaruh terhadap pengelolaan keuangan yang akan memberikan dampak terhadap kinerja dan keberlangsungan UMKM (Desiyanti, 2016). Oleh karena itu, UMKM memerlukan upaya-upaya strategis untuk mencapai kinerja yang unggul dan bisnis yang berkelanjutan.

Secara umum, UMKM sering mengalami keterlambatan dalam pengembangannya dikarenakan UMKM cenderung memiliki orientasi jangka pendek, tidak adanya konsep inovasi yang berkelanjutan, aktivitas inti bisnis yang tidak konsisten, dan sistem pengelolaan keuangan yang belum terstruktur. Selain itu sulitnya akses pembiayaan karna tidak terpenuhinya persyaratan permohonan pembiayaan juga menjadi masalah.

Tabel 1: Data Pengajuan Pembiayaan tahun

\begin{tabular}{lllcl}
\multicolumn{4}{c}{2018} \\
\hline No & Program & Jumlah & \multicolumn{2}{c}{ Verifikasi } \\
& Pembiayaan & Pemohon & L & TL \\
\hline $1 \quad$ Dana Bergulir & 32 & 26 & 6 \\
& APBD Jatim & & & \\
2 & KUR & 305 & 219 & 86 \\
Total & 337 & 245 & 92 \\
\hline \multicolumn{3}{l}{ Sumber: Dinas Koperasi dan UKM Jatim }
\end{tabular}

Jawa Timur merupakan Provinsi dengan jumlah UMKM yang cukup banyak. Namun indeks literasi dan inklusi keuangannya masih berada dibawah Provinsi lain seperti Kepuluan Riau dan Bali (OJK-RI, 2017). Laporan Akuntabilitas Dinas Koperasi dan UKM Jawa Timur (2018) menunjukkan adanya peningkatan dalam pertumbuhan koperasi dan UKM aktif namun masih belum dapat memenuhi target yang ditetapkan sebesar 6\%. Data pengajuan pembiayaan tahun 2018 juga menunjukkan bahwa beberapa UMKM tidak dapat memenuhi persyaratan untuk mendapatkan 
pembiayaan (Dinas Koperasi dan UKM Jawa Timur, 2019).

Surabaya merupakan pusat ekonomi Jawa Timur yang memiliki jumlah UMKM terbanyak bila dibandingkan dengan kotakota besar lain di Jawa Timur. Penelitian oleh Sanistasya, Raharjo, \& Iqbal (2019) mengatakan bahwa literasi keuangan dan inklusi keuangan memiliki pengaruh signifikan terhadap kinerja usaha kecil. Namun hasil tersebut berbanding terbalik dengan hasil penelitian oleh Dermawan (2019) yang menjelaskan bahwa inklusi keuangan tidak memiliki pengaruh signifikan terhadap kinerja dan keberlangsungan UMKM. Oleh karena latar belakang tersebut, penelitian ini dilakukan untuk menganalisis inklusi keuangan dan literasi keuangan terhadap kinerja dan keberlangsungan Usaha Kecil Mikro Menengah pada UMKM di Kota Surabaya.

\section{KAJIAN LITERATUR}

\section{Teori RBV (Resource Based View)}

Gagasan utama dalam teori RBV menyebutkan bahwa suatu perusahaan bisa mencapai suatu keunggulan kinerja dan keunggulan kompetitif yang berkelanjutan apabila memperoleh sumber daya yang bernilai, memiliki kemampuan berharga yang tidak ada substansinya dan tidak dapat ditiru, serta perusahaan harus memiliki kemampuan dalam menyerap dan menerapkannya (Barney, 1991). Resource Based View Theory ini mengemukakan bahwa sumber daya berwujud maupun sumber daya yang tak berwujud dalam perusahaan maupun organisasi dapat mendorong suatu perusahaan maupun organisasi dalam menyusun strategi guna mewujudkan keunggulan bersaing (Sari, 2020). Teori RBV dalam penelitian ini menjadi dasar yang menjelaskan bahwa inklusi keuangan dan literasi keuangan yang merupakan sumber daya internal perusahaan memiliki suatu nilai dan potensi dalam mendukung berjalannya suatu bisnis untuk mencapai suatu keunggulan bersaing dan pertumbuhan kinerja yang berkelanjutan.

\section{Inklusi Keuangan}

Inklusi Keuangan merupakan kajian yang menyeluruh guna menghilangkan berbagai macam hambatan terkait penggunaan dan pemanfaatan layanan jasa lembaga keuangan oleh masyarakat (Yanti, 2019). Selain itu, Strategi Nasional Keuangan Inklusif Bank Indonesia (SNKI) mendefinisikan inklusi keuangan sebagai hak bagi setiap individu dalam mengakses dan mendapatkan layanan maksimal dari lembaga keuangan secara informatif dan tepat waktu, dengan biaya terjangkau, serta tetap memperhatikan kenyamanan dan hormat terhadap harkat dan martabatnya. Penelitian ini menggunakan indikator 
Nominal: Barometer Riset Akuntansi dan Manajemen

P-ISSN: 2303-2065 E-ISSN: 2502-5430

Volume 10 No 1 (2021)

dimensi akses, dimensi kualitas, dan dimensi penggunaan untuk mengukur inklusi keuangan.

\section{Literasi Keuangan}

Literasi keuangan merupakan suatu kesatuan dari sebuah intuisi, kemampuan, pengetahuan, sika, serta tindakan yang dibutuhkan dalam mengambil keputusan terkait keuangan sehingga dicapai suatu kesejahteraan finansial seorang individu (OECD, 2016). Selain itu, Otoritas Jasa Keuangan mengartikan literasi keuangan sebagai bentuk peningkatan kualitas dalam mengambil keputusan serta mengelola keuangan untuk mencapai kesejahteraan menggunakan suatu pengetahuan, keterampilan, serta keyakinan yang yang diterapkan dalam sikap dan perilaku individu. The Association of Chartered Certified Accountants menyebutkan bahwa komponen literasi keuangan yakni termasuk didalamnya wawasan tentang konsep dari keuangan, pemahaman mengenai komunikasi tentang suatu konsep keuangan, kemampuan pengelolaan keuangan baik pribadi maupun dalam suatu perusahaan, serta kecakapan dan ketepatan dalam pengambilan keputusan keuangan dalam setiap situasi (Aribawa, 2016).

\section{Kinerja UMKM}

Kinerja UMKM dianalisis menggunakan konsep balance scorecard dalam mengukur suatu tingkat kinerja usaha mikro kecil menengah, baik dalam hal kinerja keuangan maupun non keuangan. Kinerja tersebut diukur menggunakan pendekatan non cost performance measures yang mana pengukuran kinerja dilakukan menggunakan persepsi (Robert S. Kaplan, 1996). Perspektif keuangan, perspektif pelanggan, perspektif proses bisnis internal, serta perspektif pengetahuan dan pertumbuhan merupakan perspektif yang akan digunakan dalam mengukur kinerja.

\section{Keberlangsungan UMKM}

Keberlanjutan usaha (business sustainability) suatu UMKM dapat diketahui dengan melihat tingkat keberhasilan suatu bisnis dalam melakukan inovasi, mewujudkan kesejahteraan karyawan dan pelanggan, dan mengenai return on equity bisnisnya. Hal ini akan menunjukkan bagaimana perusahaan memiliki peluang untuk berkembang dan mampu berinovasi secara berkelanjutan (Mel hudson, Andi Smart, 2001). Indikator yang digunakan dalam mengukur keberhasilan UMKM diantaranya pertumbuhan keuangan, pertumbuhan strategi, pertumbuhan struktural, dan pertumbuhan organisasional (Wickham, 2006). 
Nominal: Barometer Riset Akuntansi dan Manajemen

P-ISSN: 2303-2065 E-ISSN: 2502-5430

Volume 10 No 1 (2021)

\section{Pengembangan Hipotesis}

\section{Pengaruh Inklusi Keuangan terhadap} Kinerja UMKM

Inklusi keuangan dibutuhkan para pelaku UMKM untuk mendapatkan kemudahan dalam setiap proses bisnisnya. Salah satu faktor pendukung suatu bisnis adalah permodalan. Istiyana, Hasiah, Irmawati (2017) menyebutkan bahwa masalah yang sering dihadapi oleh pelaku UMKM yakni terkait permodalan dan proses pemasaran. Permasalah tersebut dapat diatasi dengan cara mempermudah akses terhadap layanan keuangan. Kemudahan akses terhadap layanan lembaga keuangan akan mempermudah masyarakat dan para pelaku bisnis dalam mendapatkan permodalan untuk menjalankan setiap proses bisnisnya (Alimi, 2018). Penelitian oleh Yanti (2019) menunjukkan bahwa apabila inklusi keuangan ditingkatkan, maka inklusi keuangan akan mampu memberikan pengaruh positif dan signifikan terhadap kinerja keuangan suatu bisnis. Selain itu, Sanistasya et al., (2019) juga menyebutkan bahwa inklusi keuangan memiliki pengaruh positif dan signifikan terhadap kinerja bisnis usaha kecil.

H1 : Inklusi Keuangan berpengaruh terhadap Kinerja Bisnis UMKM

\section{Pengaruh Literasi Keuangan terhadap Kinerja UMKM}

Literasi keuangan diperlukan para pelaku UMKM terlebih dalam proses penyusunan laporan keuangan bisnisnya. Seorang pemilik usaha membutuhkan suatu pengetahuan keuangan untuk mempermudah dalam melakukan pengontrolan keuangan sehingga kinerja usaha akan bisa lebih optimal (Dahmen \& Rodríguez, 2014). Menurut Anggraeni (2015) Literasi keuangan secara langsung memiliki pengaruh terhadap pola pikir seseorang yang selanjutnya akan mempengaruhi cara seseorang dalam mengambil keputusan terkait keuangan dan cara pengelolaannya.

Penelitian oleh Apristi (2017) mengatakan bahwa kinerja UMKM akan meningkat seiring dengan peningkatan literasi keuangan yang dimiliki pelakunya. Tingkat literasi yang tinggi/baik membuat para pelaku bisnis lebih berhati-hati dalam operasionalnya dan lebih mudah dalam melakukan pengelolaan sehingga kinerja usaha dapat dioptimalkan. Aribawa (2016) juga mengatakan bahwa keputusan yang yang diambil para pelaku UMKM terkait keuangan harus disertai dengan literasi keuangan yang baik. Suatu usaha akan berkembang ke arah yang lebih baik dari waktu ke waktu dengan pengambilan keputusan yang tepat. 
Nominal: Barometer Riset Akuntansi dan Manajemen

P-ISSN: 2303-2065 E-ISSN: 2502-5430

Volume 10 No 1 (2021)

H2 : Literasi Keuangan berpengaruh terhadap Keberlangsungan UMKM

\section{Pengaruh Inklusi Keuangan terhadap Keberlangsungan UMKM}

Keberlanjutan usaha (business sustainability) suatu UMKM dapat diketahui dengan melihat tingkat keberhasilan suatu bisnis dalam melakukan inovasi, mewujudkan kesejahteraan karyawan dan pelanggan, dan mengenai return on equity bisnisnya. Hal ini akan menunjukkan bagaimana perusahaan memiliki peluang untuk berkembang dan mampu berinovasi secara berkelanjutan (Mel hudson, Andi Smart, 2001). Beberapa penelitian menunjukkan bahwa kemudahan akses keuangan memiliki pengaruh dan berperan penting dalan proses pertumbuhan UMKM secara keberlanjutan. Beck \& Demirguc-kunt (2006) mengatakan bahwa inklusi keuangan memungkinkan para pelaku UMKM mengembangkan usaha dan menerapkan investasi yang lebih produktif, memanfaatkan teknologi terbaru yang akan meningkatkan daya saing dan menciptakan inovasi. Selain itu, dalam peneitian Davidsson (2015) juga menyebutkan bahwa suatu organisasi yang tidak memiliki cukup akses terhadap layanan lembaga keuangan mamiiki peluang yang cukup besar untuk mengalami kemrosotan kinerja.
H3: Inklusi Keuangan berpengaruh terhadap Keberlangsungan UMKM

Pengaruh Literasi Keuangan terhadap Keberlangsungan UMKM

Hudson \& Smart (2001) menyebutkan bahwa keberlangsungan usaha (business sustainability) dapat diketahui dari tingkat keberhasilan suatu usaha dalam memanfaatkan peluang untuk melakukan inovasi, mewujudkan kesejahteraan para karyawan dan pelanggannya, serta keberhasilan mencapai BEP dalam usahanya. Hal tersebut akan menunjukkan bahwa usaha yang dijalankan memiliki peluang untuk dapat berkembang secara berkelanjutan.

Literasi keuangan yang baik akan mempermudah para pelaku bisnis dalam proses pengambilan keputusan yang tepat di berbagai situasi. Bayrakdaro \& Botan (2014) dalam penelitiannya yang membahas kemampuan manajer untuk menggunakan instrument pasar keuangan dalam UMKM di Turki mengatakan bahwa tingkat literasi keuangan manajer meningkat dengan pelatihan keuangan. Partisipasi yang lebih besar ditunjukkan oleh para pelaku usaha dengan tingkat literasi keuangan yang tinggi. Mereka memiliki andil besar di pasar keuangan karena mampu mengurangi kendala informasi yang ada.

H4: Literasi Keuangan berpengaruh terhadap Keberlangsungan UMKM 


\section{METODE PENELITIAN}

\section{Jenis dan Sumber Data}

Penelitian ini memuat data berupa angkaangka yang dapat diukur atau dihitung secara langsung serta dapat dilakukan analisis secara statistik sehingga penelitian ini dikategorikan dalam penelitian kuantitatif (Sugiyono, 2016). Penelitian ini menggunakan sumber data primer dan sekunder. Data primer didapat langsung dari responden maupun narasumber dengan melakukan penyebaran kuesioner. Data sekunder yang didapat dari studi pustaka maupun dokumentasi seperti telaah jurnal, buku, dan secara daring yang berkaitan dengan permasalahan-permasalahan pada penelitian.

\section{Populasi dan Sampel}

Populasi dikatakan sebagai suatu bagian wilayah baik obyek maupun subyek yang telah ditentutan oleh peneliti yang mana memiliki kualitas dan karakteristik tertentu sehingga pada akhirnya dapat ditarik sebuah kesimpulan (Sugiyono, 2016). Populasi yang ditetapkan dalam penelitian ini yakni Usaha Mikro yang terdaftar menjadi binaan pada Dinas Koperasi dan Usaha Mikro Kota Surabaya sebanyak 145 UMKM serta Usaha Kecil Menengah yang berdomisili di Surabaya yang terdaftar di Dinas Koperasi dan Usaha Kecil Menengah Provinsi Jawa Timur sebanyak 66 UMKM. Kemudian dari populasi tersebut akan dilakukan penyaringan atau pengambilan sampel menggunakan metode purposive sampling. Proses penyaringan metode ini yaitu proses pemilihan sampel menggunakan pertimbangan tertentu (Sugiyono, 2016). Berikut pertimbangan dalam pemilihan sampel pada penelitian ini:

1. Usaha Mikro Kecil Menengah yang masih aktif berproduksi di wilayah Surabaya

2. Lama usaha minimal 1 tahun

3. Memiliki jumlah karyawan 1 hingga 99 orang berdasarkan kriteria yang telah ditetapkan terhadap UMKM

\section{Variabel dan Definisi Operasional}

Penelitian ini menggunakan variabel laten, konstruk, atau variabel tidak teramati intangibles. Variabel laten yang digunakan berupa variabel eksogen dan variabel endogen. Variabel eksogen merupakan variabel yang tidak dipengaruhi oleh variabel lain, sedangkan variabel endogen merupakan variabel yang dipengaruhi oleh variabel lain baik secara langsung (direct) maupun tidak langsung (indirect) (Ghozali, 2016). Variabel laten eksogen yang digunakan dalam penelitian ini adalah inklusi keuangan dan literasi keuangan. Sedangkan variabel laten endogen yang digunakan adalah kinerja dan keberlangsungan UMKM. Berikut gambaran definisi variabel yang akan dioperasionalkan dalam penelitian ini. 
Nominal: Barometer Riset Akuntansi dan Manajemen

P-ISSN: 2303-2065 E-ISSN: 2502-5430

Volume 10 No 1 (2021)

Tabel 2: Variabel Operasional

\begin{tabular}{|c|c|c|c|}
\hline Variabel & Indikator & Ref & Skala \\
\hline $\begin{array}{l}\text { Inklusi } \\
\text { Keuangan }\end{array}$ & $\begin{array}{l}\text { oAccess } \\
\circ \text { Quality } \\
\circ \text { Usage }\end{array}$ & $\begin{array}{l}\text { AFI } \\
\text { (Afillian } \\
\text { ce } \\
\text { Financi } \\
\text { al } \\
\text { Inclusio } \\
n \text { ) }\end{array}$ & Likert \\
\hline $\begin{array}{l}\text { Literasi } \\
\text { Keuangan }\end{array}$ & $\begin{array}{l}\text { - Financial } \\
\text { planning, } \\
\text { budgeting \& } \\
\text { control } \\
\text { - Book-keeping } \\
\text { - Understandin } \\
\text { g of funding } \\
\text { source } \\
\text { - Business } \\
\text { terminology } \\
\text { - Finance \& } \\
\text { information } \\
\text { skill } \\
\text { - Use to } \\
\text { technology } \\
\text { - Risk } \\
\text { management } \\
\text { (insurance) }\end{array}$ & $\begin{array}{l}\text { Fatoki, } \\
\text { O. } \\
(2014)\end{array}$ & Likert \\
\hline $\begin{array}{l}\text { Kinerja } \\
\text { UMKM }\end{array}$ & $\begin{array}{l}\text { o Financial } \\
\text { Perspective } \\
\text { o Customer } \\
\text { Perspective } \\
\text { o Internal- } \\
\text { Business- } \\
\text { Process } \\
\text { Perspective } \\
\text { O Learning \& } \\
\text { Growth } \\
\text { Perspective }\end{array}$ & $\begin{array}{l}\text { Kaplan } \\
\& \\
\text { Norton, } \\
2005\end{array}$ & Likert \\
\hline $\begin{array}{l}\text { Keberlan } \\
\text { g-sungan } \\
\text { UMKM }\end{array}$ & $\begin{array}{l}\text { - Financial } \\
\text { Growth } \\
\text { - Strategic } \\
\text { Growth } \\
\text { - Structural } \\
\text { Growth } \\
\text { - Organisation } \\
\text { al Growth }\end{array}$ & $\begin{array}{l}\text { Philip } \\
\text { Wickha } \\
\text { m } \\
(2006)\end{array}$ & Likert \\
\hline
\end{tabular}

Skala yang digunakan untuk mengukur keseluruhan variabel dalam penelitian ini adalah Skala Likert. Penggunaan skala ini adalah untuk mengukur sikap, pendapat, serta persepsi seseorang ataupun kelompok orang mengenai suatu fenomena sosial (Sugiyono, 2016). Terdapat empat tingkatan dalam skala Likert yang dipakai penulis dalam penelitian ini yakni dari 1 untuk sangat tidak setuju, 2 untuk tidak setuju, 3 untuk setuju, dan 4 untuk sangat setuju. Penggunaan skala Likert dengan 4 poin bertujuan untuk mengurangi timbulnya bias dalam hasil yang akan diperoleh dalam penelitian ini.

\section{Teknik Pengumpulan Data}

Penelitian ini bersifat kuantitatif. Oleh karena itu, peneliti menggunakan data primer dan sekunder guna mendukung tingkat akurasi atau hasil dari penelitian ini. Penelitian ini menggunakan teknik pengumpulan data berupa kuesioner online, studi pustaka, dan wawancara online.

\section{Teknik Analisis Data}

Penelitian ini menggunakan pendekatan Partial Least Square (PLS) dalam melakukan analisis data. Peneitian ini menggunakan pendekatan PLS dengan pertimbangan karena variabel terikat yang digunakan lebih dari satu dan dianalisis langsung menggunakan indikator yang berbentuk reflektif. PLS juga tidak mensyaratkan jumlah sampel yang besar sehingga sampel dalam penelitian ini masih 
memenuhi syarat untuk dilakukan pengujian. Selain itu, PLS tidak mensyaratkan data penelitian harus terdistribusi normal multivariate, dan model juga tidak diharuskan memenuhi goodness of fit.

Tabel 3: Kriteria Penilaian Inner Model

\begin{tabular}{|c|c|}
\hline $\begin{array}{c}\text { Kriteria } \\
\text { Pengukuran } \\
\end{array}$ & Keterangan \\
\hline $\mathrm{R}$-Square $\left(\mathrm{R}^{2}\right)$ & $\begin{array}{l}\text { Hasil } \mathrm{R}^{2} 0,67,0,33 \text {, dan } \\
0,19 \text { mengindikasikan } \\
\text { bahwa model kuat, } \\
\text { moderate dan lemah }\end{array}$ \\
\hline $\begin{array}{l}\text { F-Square atau } \\
\text { Effect Size }\end{array}$ & $\begin{array}{l}\text { Nilai F menunjukkan } \\
\text { tingkat pengaruh } \\
\text { prediktor variabel laten } \\
\text { yakni sebesar } 0,02 \text {, } \\
\text { (lemah), } 0,15 \text { (medium), } \\
0,35 \text { (besar). }\end{array}$ \\
\hline $\begin{array}{l}\text { Q-Square } \\
\text { Predictive } \\
\text { Relevance }\end{array}$ & $\begin{array}{l}\text { Nilai } \mathrm{Q}^{2}>0 \\
\text { mengindikasikan bahwa } \\
\text { model memiliki } \\
\text { predictive relevance, } \\
\text { sedangkan } \mathrm{Q}^{2}<0 \\
\text { mengindikasikan bahwa } \\
\text { model kurang memiliki } \\
\text { predictive relevance. }\end{array}$ \\
\hline $\begin{array}{l}\text { Average Path } \\
\text { Coefficient } \\
\text { (APC) }\end{array}$ & $\begin{array}{l}\text { Nilai P Value } \leq 0.05 \\
\text { menunjukkan model } \\
\text { dapat diterima }\end{array}$ \\
\hline $\begin{array}{l}\text { Average } R- \\
\text { Square (ARS) }\end{array}$ & $\begin{array}{l}\text { Nilai P Value } \leq 0.05 \\
\text { menunjukkan model } \\
\text { dapat diterima }\end{array}$ \\
\hline $\begin{array}{l}\text { Average Block } \\
\text { Variance } \\
\text { Inflation (AVIV) }\end{array}$ & $\begin{array}{l}\text { Nilai P Value } \leq 5 \\
\text { menunjukkan bahwa } \\
\text { model dapat diterima dan } \\
\text { nilai } \leq 3 \text { menunjukkan } \\
\text { bahwa model ideal. }\end{array}$ \\
\hline
\end{tabular}

kuantitatif yang kemudian diolah menggunakan program WarpPLS 5.0. Data tersebut kemudian dianalisis dengan analisis statistik deskriptif serta evaluasi model kausal PLS yang didalamnya terdapat evaluasi model pengukuran (outer model) dan model struktural (inner model), serta uji hipotesis. Kriteria yang digunakan dalam penilaian inner model disajikan pada tabel 3.

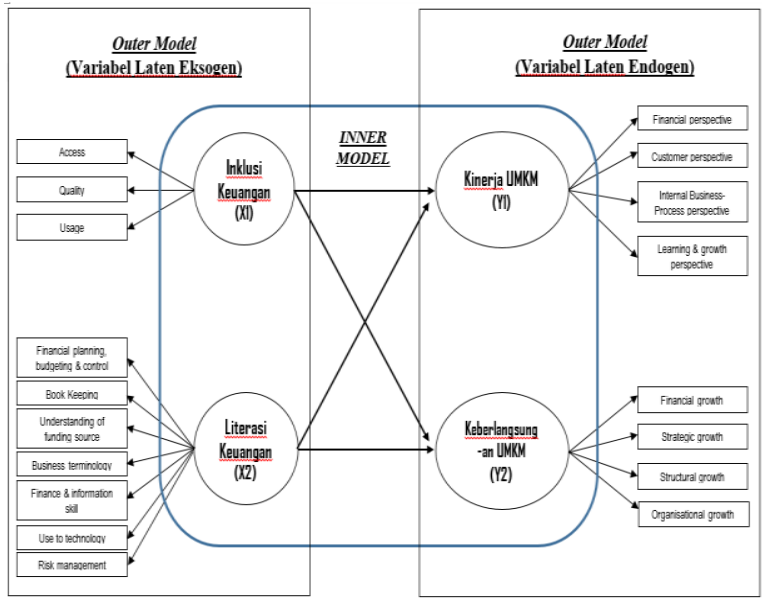

Gambar 2: Structural Equation Model (SEM)

HASIL PENELITIAN DAN

\section{PEMBAHASAN}

\section{Analisis Statistik Deskriptif}

Kuesioner online telah disebarkan dan telah terkumpul sejumlah 113 data dari responden yang kemudian dilakukan analisis dan pengolahan data. Ringkasan data mengenai demografi responden dapat dilihat dalam tabel 4. Berdasarkan tabel 4 dapat diketahui bahwa $91 \%$ pelaku usaha adalah perempuan. Rata-rata usia para pelaku UMKM adalah 30 sampai dengan 50 tahun dengan latar belakang pendidikan paling banyak adalah SMA sederajat. Ringkasan demografi responden disajikan pada tabel 4.

Penelitian ini mendeskripsikan karakteristik UMKM berdasarkan beberapa kategori. Hasil rekapitulasi data menunjukkan bahwa usaha yang dijalankan para pelaku UMKM kebanyakan bergerak di bidang makanan dan minuman dengan 
presentase sebanyak $63 \%$. Jumlah karyawan yang dimiliki rata-rata 1-4 orang dengan lama usaha yang dijalankan berkisar antara satu sampai dengan sepuluh tahun. Ringkasan karakteristik responden disajikan pada tabel 5 .

Tabel 4: Demografi Responden

\begin{tabular}{lccc}
\hline \multicolumn{2}{c}{ Keterangan } & $\begin{array}{c}\text { Jumlah } \\
(\mathbf{n = 1 1 3})\end{array}$ & $\begin{array}{c}\text { Presentase } \\
(\mathbf{\%})\end{array}$ \\
\hline Jenis & Laki-Laki & 10 & $9 \%$ \\
Kelamin & Perempuan & 103 & $91 \%$ \\
Usia & $<18$ th & 0 & $0 \%$ \\
& $19-29$ th & 7 & $6 \%$ \\
& $30-39$ th & 36 & $32 \%$ \\
& $40-49$ th & 41 & $36 \%$ \\
Pendidik- & $>$ 50 th & 29 & $26 \%$ \\
an & SD & 5 & $4 \%$ \\
& SMP & 8 & $7 \%$ \\
& SMA/SMK & 52 & $46 \%$ \\
& D3 & 5 & $4 \%$ \\
& S1 & 40 & $35 \%$ \\
& S2 & 3 & $3 \%$ \\
& S3 & 0 & $0 \%$ \\
\hline \multirow{4}{*}{} & & &
\end{tabular}

Tabel 5: Karakteristik Responden

\begin{tabular}{|c|c|c|c|}
\hline & Kategori & $\begin{array}{l}\text { Jumlah } \\
(n=113)\end{array}$ & $\begin{array}{l}\text { esentase } \\
(\%)\end{array}$ \\
\hline Jenis & Fashion & 20 & $18 \%$ \\
\hline Usaha & Kerajinan Tangan & & \\
\hline & Rumah Tangga & 22 & $19 \%$ \\
\hline & Makanan \& & & \\
\hline & Minuman & 71 & $63 \%$ \\
\hline Jumlah & 1-4 orang & 103 & $91 \%$ \\
\hline Karyawan & 5-19 orang & 9 & $8 \%$ \\
\hline & 20-99 orang & 1 & $1 \%$ \\
\hline Lama & 1-5 tahun & 75 & $66 \%$ \\
\hline Usaha & 6-10 tahun & 31 & $27 \%$ \\
\hline & $>10$ tahun & 7 & $6 \%$ \\
\hline Omset per & $<\mathrm{Rp} 25.000 .000$ & 97 & $86 \%$ \\
\hline bulan & Rp25.000.000 - & & \\
\hline & Rp100.000.000 & 10 & $9 \%$ \\
\hline & Rp100.000.001 - & & \\
\hline & Rp200.000.000 & 1 & $1 \%$ \\
\hline & Rp200.000.001 - & & \\
\hline & Rp1.000.000.000 & 3 & $3 \%$ \\
\hline & $>$ Rp1.000.000.000 & 2 & $2 \%$ \\
\hline
\end{tabular}

\section{Evaluasi Outer Model}

\section{Validitas Konvergen (Convergent validity)}

Berdasarkan hasil output dapat diketahui bahwa nilai AVE dan composite reliability dalam penelitian ini telah memenuhi kriteria yang syaratkan yakni AVE > 0.50 serta composite reliability > 0.70 . Selanjutnya dapat disimpulkan bahwa convergent validity telah terpenuhi.

Tabel 6: Output Latent Variable Coefficient Setelah Penghapusan

\begin{tabular}{lcccl}
\hline & INKA & LIKA & KIUS & KEUS \\
\hline R-squared & & & 0.373 & 0.28 \\
$\begin{array}{l}\text { Adj. R- } \\
\text { Squared }\end{array}$ & & & 0.362 & 0.275 \\
$\begin{array}{l}\text { Composite } \\
\text { reliability }\end{array}$ & 0.912 & 0.897 & 0.907 & 0.840 \\
$\begin{array}{l}\text { Cronbach's } \\
\text { alpha }\end{array}$ & 0.896 & 0.864 & 0.885 & 0.749 \\
$\begin{array}{l}\text { Avg. var. } \\
\text { extrac. }\end{array}$ & 0.570 & 0.557 & 0.521 & 0.574 \\
$\begin{array}{l}\text { Full collin. } \\
\text { VIF }\end{array}$ & 1.177 & 1.892 & 1.891 & 1.664 \\
Q-Squared & & & 0.384 & 0.292 \\
\hline
\end{tabular}

\section{Validitas Diskriminan (Discriminant} Validity)

Nilai dalam kurung pada tabel menunjukkan akar kuadrat AVE sedangkan lainnya menunjukkan korelasi antara variabel laten di dalam model. Tabel menunjukan bahwa seluruh nilai kuadrat AVE lebih besar daripada korelasi antar dua variabel laten lainnya baik secara horizontal maupun vertikal. Nilai kuadrat AVE yang dimiliki juga menunjukkan nilai diatas 0.50. AVE dikatakan baik adalah ketika bernilai lebih besar dari 0.50 (Ghozali, 2016). Dari hasil tersebut dapat disimpulkan bahwa 
Nominal: Barometer Riset Akuntansi dan Manajemen

P-ISSN: 2303-2065 E-ISSN: 2502-5430

Volume 10 No 1 (2021)

keseluruhan variabel laten pada penelitian ini memiliki discriminant validity yang baik.

Tabel 7: Output Correlation Among Latent Variables

\begin{tabular}{lllll}
\hline & INKA & LIKA & KIUS & KEUS \\
\hline INKA & $(0.755)$ & 0.384 & 0.259 & 0.180 \\
LIKA & 0.384 & $(0.746)$ & 0.611 & 0.536 \\
KIUS & 0.259 & 0.611 & $(0.722)$ & 0.590 \\
KEUS & 0.180 & 0.536 & 0.590 & $(0.757)$ \\
\hline
\end{tabular}

\section{Realibilitas}

Hasil output tabel 8 menunjukkan bahwa composite reliability dan conbach's alpha dari semua konstruk bernilai lebih besar dari 0.70. oleh karena itu, dapat dikatakan bahwa reliabilitas semua konstruk dalam penelitian ini sudah baik dan telah kriteria yang telah ditetapkan.

Tabel 8: Output Composite Reliability dan Conbach's Alpha

\begin{tabular}{lcccc}
\hline \multicolumn{1}{c}{ INKA } & LIKA & KIUS & KEUS \\
\hline $\begin{array}{l}\text { Composite } \\
\text { reliability }\end{array}$ & 0.912 & 0.897 & 0.907 & 0.840 \\
$\begin{array}{l}\text { Cronbach's } \\
\text { alpha }\end{array}$ & 0.895 & 0.864 & 0.885 & 0.749 \\
\hline
\end{tabular}

\section{Evaluasi Model Struktural (Inner Model)}

Goodness of Fit

Hasil output tabel 9 menunjukkan nilai sebesar 0.302 dengan p-value $<0.001$ untuk APC dan nilai sebesar 0.331 dengan p-value $<0.001$ untuk ARS. Kriteria penilaian APC dan ARS dalam penelitian ini telah terpenuhi karena memiliki nilai $\mathrm{p}<0.001$. Sedangkan untuk average varians factor (AVIF) menunjukkan indeks 1.173 yang mana telah memenuhi kriteria yaitu $<=3.3$ artinya tidak ditemukan multikolinearitas dalam model.
Sehingga, dapat dikatakan bahwa model yang digunakan dalam penelitian ini sudah baik dan dapat diterima.

Tabel 9: Output Goodness of Fit

\begin{tabular}{|c|c|c|c|}
\hline $\begin{array}{c}\text { Ukuran } \\
\text { Fit } \\
\text { Model }\end{array}$ & $\begin{array}{c}\text { Output } \\
\text { Model Fit } \\
\text { Indices and } \\
\text { P Value }\end{array}$ & Kriteria & Keterangan \\
\hline APC & $\begin{array}{c}0.302 \\
\mathrm{P}<0.001 \\
0.331\end{array}$ & $\mathrm{P}<0.05$ & Baik \\
\hline ARS & $P<0.001$ & $\begin{array}{c}\mathrm{P}<0.05 \\
\text { AVIF }<5 \\
\text { ideally } \\
<=3.3\end{array}$ & Baik \\
\hline
\end{tabular}

\section{Koefisien Determinasi $\left(\mathbf{R}^{2}\right)$}

Hasil output tabel 10 menunjukkan nilai R-square adalah 0.373 untuk variabel KIUS dan 0.288 untuk variabel KEUS. Hasil tersebut menjelaskan bahwa variabel kinerja keuangan dan keberlangsungan usaha masih dapat dijelaskan oleh variabel inklusi keuangan dan literasi keuangan. Hasil pengujian R-square 0.373 dan 0.288 mengindikasikan bahwa variabel kinerja usaha dan keberlangsungan usaha termasuk dalam kategori "moderat", sehingga masih dapat diterima dan dianggap cukup baik.

Tabel 10: Output R-square

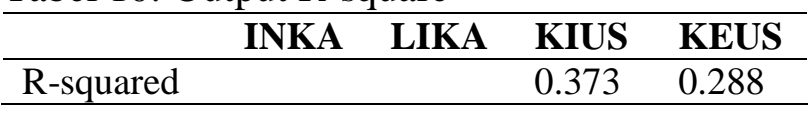

\section{Effect Size $\left(\mathbf{f}^{2}\right)$}

Hasil pengujian Path Coefficient dan P-value pada tabel 11 menunjukkan bahwa variabel inklusi keuangan memiliki nilai 0.070 yang berarti hanya dapat menjelaskan $7.0 \%$ pengaruhnya terhadap variabel kinerja 
usaha. Variabel literasi keuangan sebesar 0.366 berarti $36.6 \%$ variabel tersebut dapat menjelaskan pengaruhnya terhadap variabel kinerja usaha. Selanjutnya, nilai inklusi keuangan sebesar 0.050 mengindikasikan bahwa variabel tersebut $5.0 \%$ pengaruhnya terhadap variabel keberlangsungan usaha. Nilai variabel literasi keuangan sebesar 0.293 menjelaskan bahwa variabel tersebut $29.3 \%$ pengaruhnya terhadap variabel keberlangsungan usaha.

Tabel 11: Output Path Coefficient and P

\begin{tabular}{lcccc} 
& Value & & & \\
\hline & INKA & LIKA & KIUS & KEUS \\
\hline INKA & & & & \\
LIKA & & & & \\
KIUS & 0.070 & 0.366 & & \\
KEUS & 0.050 & 0.293 & & \\
\hline
\end{tabular}

Berdasarkan hasil pengujian tersebut dapat dikatakan bahwa variabel inklusi keuangan tidak berpengaruh terhadap variabel kinerja usaha dan keberlangsungan usaha. Sedangkan, literasi keuangan memiliki pengaruh terhadap variabel kinerja usaha dan keberlangsungan usaha.

\section{Predictive Relevance $\left(\mathbf{Q}^{2}\right)$}

Pengujian Q-Square pada tabel 12 memperlihatkan hasil 0.397 dan 0.299. hasil tersebut menunjukkan nilai yang lebih besar dari 0 (nol), sehingga dari hasil tersebut dapat dikatakan bahwa model penelitian ini bersifat predictive relevance atau dinilai telah relevan.

Tabel 12: Output uji Q-Square

\begin{tabular}{|c|c|c|c|c|}
\hline & INKA & LIKA & KIUS & KEUS \\
\hline$-S c$ & & & 0.397 & 0.299 \\
\hline
\end{tabular}

\section{Pengujian Hipotesis}

Penelitian ini menggunakan simulasi model bootstrapping terhadap sampel untuk menguji setiap hubungan variabel laten endogen. Pengujian setiap hubungan ini memiliki tujuan untuk meminimalisir masalah ketidaknormalan dalam data penelitian. Berikut hasil analisis SEM PLS dengan metode bootsrapping:

Tabel 13: Hasil Pengujian path coefficient dan P Value

\begin{tabular}{|c|c|c|c|c|}
\hline Hipo & Variabel & $\begin{array}{l}\text { Path } \\
\text { Coeff }\end{array}$ & $\begin{array}{c}\mathbf{P} \\
\text { Value }\end{array}$ & Ket \\
\hline $\mathrm{H} 1$ & & 0.028 & 0.40 & $\begin{array}{c}\text { Tidak } \\
\text { Signifikar }\end{array}$ \\
\hline $\mathrm{H} 2$ & & 0.600 & $<0.001$ & Signifika \\
\hline $\mathrm{H} 3$ & & -0.031 & 0.40 & $\begin{array}{c}\text { Tidak } \\
\text { Signifikar }\end{array}$ \\
\hline $\mathrm{H} 4$ & $\begin{array}{c}\text { LIKA } \rightarrow \\
\text { KEUS }\end{array}$ & 0.547 & $<0.001$ & Signifikan \\
\hline
\end{tabular}

\section{Pengujian Hipotesis 1}

Hipotesis 1 menyatakan bahwa inklusi keuangan berpengaruh terhadap kinerja usaha. Pengujian koefisien jalur antara inklusi keuangan (INKA) dengan kinerja usaha (KIUS) memperlihatkan nilai path coefficient INKA $\rightarrow$ KIUS sebesar 0.028. Nilai tersebut berada pada rentang -0.1 hingga 0.1 dan tidak signifikan pada $\alpha=0$. 05. Sehingga, dapat disimpulkan bahwa Hipotesis $1(\mathrm{H} 1)$ pada penelitian ini ditolak.

\section{Pengujian Hipotesis 2}

Hipotesis 2 menyatakan bahwa literasi keuangan berpengaruh terhadap kinerja usaha. Hasil pengujian koefisien jalur antara 
literasi keuangan (LIKA) dengan kinerja usaha (KIUS) menunjukkan nilai path coefficient LIKA $\rightarrow$ KIUS sebesar 0.600 . Nilai tersebut lebih besar dari 0.1 dan signifikan pada $\alpha=0$. 05. Sehingga, dapat disimpulkan bahwa Hipotesis 2 (H2) pada penelitian ini diterima.

\section{Pengujian Hipotesis 3}

Hipotesis 3 menyatakan bahwa inklusi keuangan berpengaruh terhadap keberlangsungan usaha. Pengujian koefisien jalur antara inklusi keuangan (INKA) dengan keberlangsungan usaha (KEUS) menunjukkan nilai path coefficient INKA $\rightarrow$ KEUS sebesar -0.031 . Nilai tersebut berada pada rentang -0.1 hingga 0.1 dan tidak signifikan pada $\alpha=0$. 05. Oleh karena itu, dapat disimpulkan bahwa Hipotesis 3 (H3) pada penelitian ini ditolak.

\section{Pengujian Hipotesis 4}

Hipotesis 4 menyatakan bahwa literasi keuangan berpengaruh terhadap keberlangsungan usaha. Pengujian koefisien jalur antara literasi keuangan (LIKA) dengan keberlangsungan usaha

(KEUS) menunjukkan nilai path coefficient INKA $\rightarrow$ KEUS sebesar 0.547. Nilai tersebut lebih besar dari 0.1 dan signifikan pada $\alpha=0.05$. Oleh karena itu, dapat disimpulkan bahwa Hipotesis 4 (H4) pada penelitian ini diterima.

Selain dengan hasil output path coefficient dan P-value pada tabel 13, dapat dilihat juga hasil pengujian pengaruh langsung pada diagram jalur output WarpPLS 5.0 disajikan pada gambar 3

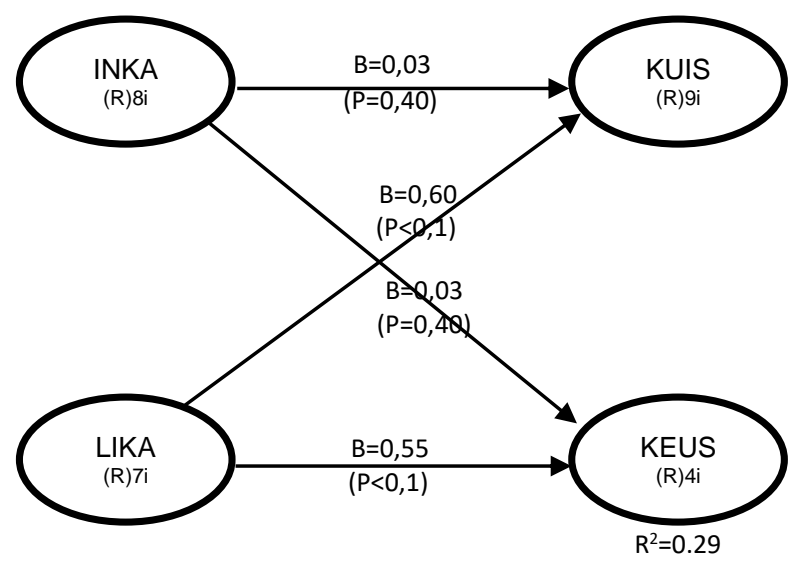

Gambar 3: Jalur output WarpPLS 5.0

\section{Pengaruh Inklusi Keuangan terhadap Kinerja Usaha}

Pengujian yang telah dilakukan menunjukkan hasil bahwa inklusi keuangan tidak memiliki pengaruh terhadap kinerja UMKM. Inklusi keuangan berupa kemudahan akses, kualitas, dan penggunaan layanan lembaga keuangan oleh UMKM. Ketiga hal tersebut tidak berpengaruh terhadap kinerja usaha UMKM. Saat ini telah terdapat Financial Tecnology (Fintech) yang menggantikan sistem kerja lembaga keuangan tradisional. Marginingsih (2019) menjelaskan bahwa fintech oleh lembaga keuangan mampu meningkatkan inklusi keuangan nasional. Data lain juga menunjukkan bahwa masyarakat yang memiliki latar belakang pendidikan tinggi seperti pada Survei Nasional Literasi Keuangan (SNLKI) tahun 2016 oleh OJK 


\section{Nominal: Barometer Riset Akuntansi dan Manajemen}

P-ISSN: 2303-2065 E-ISSN: 2502-5430

Volume 10 No 1 (2021)

memperlihatkan bahwa responden dengan tingkat pendidikan Perguruan Tinggi memiliki indeks inklusi keuangan tertinggi dengan $88 \%$ dibandingkan dengan latar belakang pendidikan lain.

Analisis diatas sesuai dengan Analisis diatas relevan dengan penelitian oleh (Marginingsih, 2019) yang mengemukakan bahwa kemampuan adaptasi teknologi (fintech) akan mempengaruhi pengembangan strategi perusahaan. Proses adaptasi terhadap fintech sangat dibutuhkan untuk menghilangkan kendala inklusi keuangan sehingga inklusi keuangan tidak lagi menghambat kinerja bisnis UMKM. Otoritas Jasa Keuangan mendata bahwa Jawa Timur menjadi daerah ketiga dengan penyaluran pinjaman terbesar di Indonesia pada industry fintech. Penelitian ini dilakukan di Kota Surabaya yang merupakan pusat bisnis dan perdagangan di Jawa Timur. Masyarakat Surabaya yang telah mengadaptasi fintech dalam kesehariannya memiliki pola pikir yang luas sehingga lebih dapat memanfaatkan peluang yang ada untuk meningkatkan kinerja usahanya. Apabila pola pikir para pelaku bisnis masih terbatas pada pengembangan usaha jangka pendek dan terbatas pada akses keuangan secara tradisional, maka akan sulit untuk mengembangkan suatu usaha. Oleh karena itu, inklusi keuangan dalam penelitian ini tidak lagi memiliki pengaruh yang signifikan terhadap kinerja UMKM dikarenakan pengimplementasian fintech yang baik telah membuka pola pikir para pelaku UMKM menjadi lebih luas. Hal ini relevan terhadap hasil penelitian oleh Dermawan (2019) yang menyebutkan bahwa tingkat inklusi keuangan tidak berpengaruh terhadap kinerja UMKM.

Pengaruh Literasi Keuangan terhadap Kinerja Usaha

Pengujian terhadap variabel Literasi Keuangan memperlihatkan adanya pengaruh terhadap kinerja UMKM di Kota Surabaya. Pengujian yang telah dilakukan membuktikan bahwa Literasi Keuangan memiliki kontribusi besar dalam mendukung peningkatan kinerja UMKM. Faktor perencanaan keuangan yang baik, penggunaan informasi dan teknologi terkini, serta pembukuan membantu para pelaku UMKM untuk memperbaiki dan meningkatkan kinerja usahanya.

Hasil analisis tersebut sesuai dengan Resource Based Theory (RBV) yang dikemukakan oleh Barney (1991). Teori tersebut memberikan pandangan bahwa sumber daya pelaku usaha berupa literasi keuangan dapat menjadi nilai yang berharga bagi usaha tersebut dalam mencapai suatu keunggulan kinerja serta keunggulan kompetitif. Sehingga dalam penelitian ini kinerja usaha sektor UMKM sangat 
dipengaruhi oleh tingkat literasi keuangan yang dimiliki. Hal ini relevan dengan penelitian oleh Apristi (2017) yang mengatakan bahwa kinerja UMKM akan meningkat seiring dengan peningkatan literasi keuangan.

\section{Pengaruh Inklusi Keuangan terhadap}

\section{Keberlangsungan Usaha}

Pengujian yang telah dilakukan menunjukkan hasil bahwa Inklusi keuangan tidak berpengaruh terhadap keberlangsungan UMKM. Kemudahan akses terhadap produk serta layanan lembaga keuangan telah mampu dimanfaatkan secara maksimal oleh pelaku usaha UMKM di Kota Surabaya. Para pelaku UMKM Kota Surabaya yang mana rata-rata memiliki pendidikan akhir SMA/SMK dan lebih dari 35\% memiliki pendidikan akhir Sarjana membuat mereka dengan mudah memanfaatkan fintech dengan baik sehingga membuat inklusi keuangan tidak lagi memiliki pengaruh yang terhadap pengembangan keberlangsungan usaha.

Murtadho (2016) menyebutkan bahwa tingkat inklusi keuangan masayarakat Kota Surabaya sangat tinggi dimana sebesar $73,6 \%$ masyarakat telah banyak yang menggunakan jasa perbankan maupaun jasa keuangan lain dalam mengelola keuangannya. Hal ini juga didukung oleh tingkat literasi keuangan masyarakat Kota Surabaya yang cukup tinggi sehingga dapat mengadaptasi teknologi keuangan (fintech) dengan baik. Hasil penelitian ini relevan dengan penelitian oleh Dermawan (2019) yang mengemukakan hal yang sama bahwa tingkat inklusi keuangan pelaku usaha mikro tidak memiliki pengaruh terhadap keberlangsungan usaha dikarenakan semua itu bergantung pada pola pikir pemilik usaha tersebut.

\section{Pengaruh Literasi Keuangan terhadap Keberlangsungan Usaha}

Penelitian yang telah dilakukan menunjukkan hasil bahwa literasi keuangan memiliki pengaruh langsung terhadap keberlangsungan usaha. Literasi keuangan diantaranya adalah pengetahuan akan perencanaan dan pengelolaan keuangan, informasi dan teknologi keuangan, serta pengetahuan mengenai investasi dan manajemen risiko.

Hasil analisis tersebut sesuai dengan teori Resourse Based View yang mengemukakan bahwa suatu usaha dapat mencapai suatu pertumbuhan harus didukung oleh sumber daya unggul yang bernilai tinggi. Sumber daya yang dapat dimanfaatkan dalam hal ini yakni literasi keuangan yang dimiliki para pelaku usaha. Ari Susanti (2019) menyebutkan bahwa pengetahuan yang baik mengenai pengelolaan keuangan dan risikonya serta pemahaman mengenai bagaimana 
memanfaatkan informasi dan teknologi terkini membantu para pelaku usaha dalam membuat strategi usaha dan merencanakan langkah untuk meminimalisis risiko sehingga dapat menjaga keberlangsungan usaha dimasa yang akan datang.

Penelitian ini relevan dengan penelitian oleh Wise (2013) yang mengatakan bahwa mereka yang memiliki literasi keuangan yang baik dan mampu mengimplementasikannya serta mampu memanfaatkan informasi keuangan memiliki keberhasilan usaha yang lebih baik. Selain itu, dalam penelitian oleh Bahri \& Nisa (2017) menyebutkan bahwa pengetahuan dan pemahaman keuangan berperan penting dalam pengambilan keputusan oleh para pelaku bisnis dalam menyelesaikan berbagai masalah keuangan yang mana keputusan tersebut akan mempengaruhi pertumbuhan atau keberlanjutan usaha jangka panjang.

\section{SIMPULAN DAN SARAN}

Penelitian ini dilakukan untuk menguji pengaruh inklusi keuangan dan literasi keuangan terhadap kinerja dan keberlangsungan usaha mikro kecil menengah di Kota Surabaya. Penelitian ini dianalisis dengan metode Partial Least Square. Penelitian ini menyimpulkan bahwa inklusi keuangan tidak berpengaruh terhadap kinerja dan keberlangsungan UMKM di Kota Surabaya. Sedangkan Literasi keuangan memiliki pengaruh terhadap kinerja dan keberlangsungan UMKM di Kota Surabaya.

Penelitian ini masih memiliki keterbatasan dalam setiap prosesnya. Saran serta masukan yang dapat diberikan untuk penelitian berikutnya yakni memperluas objek penelitian baik dari skala ukuran maupun wilayah penelitian sehingga jumlah sampel akan lebih besar dan memungkinkan berkurangnya jumlah penghapusan indikator dalam pengujian.

\section{DAFTAR PUSTAKA}

Alimi, L.(2018). Penggunaan Rekening Kredit dan Penggunaan Rekening DPK Bank Umum terhadap Kredit UMKM di Indonesia ( Studi Kasus Tahun 20122016 ).

Anggraeni, B. (2015). Pengaruh Tingkat Literasi Keuangan Pemilik Usaha Terhadap Pengelolaan Keuangan. Jurnal Vokasi Indonesia, 3.

Apristi, M. (2017). Pengaruh literasi keuangan terhadap kinerja dan keberlanjutan umkm di kota surabaya.

Ari, Susanti, E. (2019). Literasi Keuangan Pemilik Usaha terhadap Keberlangsungan Usaha (Business Sustainability) Pada UMKM Rotan Desa Trangsan, Jawa Tengah. Buletin Bisnis Dan Manajemen.

Aribawa, D. (2016). Pengaruh literasi keuangan terhadap kinerja dan keberlangsungan UMKM di Jawa Tengah. Jurnal Siasat Bisnis.

Badan Kebijakan Fiskal, K. (n.d.). Masalah Pengangguran dan Kemiskinan. Retrieved February 2, 2020, from Badan Kebijakan Fiskal Kemenkeu 
Bahri, S., \& Nisa, Y. C. (2017). Jurnal ilmiah manajemen \& bisnis. Jurnal Ilmiah Manajemen \& Bisnis, 18(1), 9-15.

Bank Indonesia, D. P. A. K. dan U. (2015). Booklet Keuangan Inklusif. Bank Indonesia.

Barney, J. B. (1991). Firm Reources ad Sustained Competitive Advantege. Journal of Management, Vol. 17, pp. 99-120.

Bayrakdaro, A., \& Botan, Ş. (2014). Financial Literacy Training As a Strategic Management Tool Among Small - Medium Sized Businesses Operating In Turkey. 150, 148-155.

Beck, T., \& Demirguc-kunt, A. (2006). Small and medium-size enterprises: Access to finance as a growth constraint. 30, 2931-2943.

Dahmen, P., \& Rodríguez, E. (2014). Financial Literacy and the Success of Small Businesses: An Observation from a Small Business Development Center.

Davidsson, P. (2015). Small Firm Growth Small Firm Growth Per Davidsson School of Management Queensland University of Technology ( and Jönköping International Business School ) Gardens Point, Brisbane 4001 Queensland, Australia Leona Achtenhagen Jönköping International Busin. (January 2010).

Dermawan, T. (2019). Pengaruh Literasi, Inklusi dan Pengelolaan Keuangan Terhadap Kinerja Dan Keberlanjutan Umkm ( Studi Pada Pelaku Usaha Mikro Mahasiswa Universitas Brawijaya).

Desiyanti, R. (2016). Literasi dan Inklusi Keuangan serta Indeks Utilitas UMKM di Padang. BISMAN Jurnal Bisnis \& Manajemen, 2(2), 122-134.

Factbook, T. W. (2020). Country
Comparison: Population. Retrieved February 2, 2020, from Central Intellegence Agency.

Ghozali, P. D. H. I. (2016). Aplikasi Analisis Multivariate (8th ed.). Semarang: Badan penerbit Universitas Diponegoro.

Istiyana, Hasiah, Irmawati, A. N. I. (2017). IBM Pelatihan dan Pendampingan Penyusunan Laporan Keuangan Berbasis EMKM. 2017(20), 104-108.

Marginingsih, R. (2019). Analisis SWOT Technology Financial ( FinTech ) Terhadap Industri Perbankan.

Mel hudson, Andi Smart, M. B. (2001). theory and Practice in SME Performance Measure System.

Murtadho, M. (2016). Inklusi dan Literasi Keuangan (Studi pada Masyarakat Kota Surabaya). Business and Finance Journal, 1(2).

OECD. (2016). OECD/INFE International Survey of Adult Financial Literacy Competencies. Oecd, 1-100.

OJK-RI. (2017). Strategi Nasional Literasi Keuangan Indonesia (Revisit 2017). Otoritas Jasa Keuangan, 1-99.

Robert S. Kaplan, D. P. N. (1996). The Balanced Scorecard.

Sanistasya, P. A., Raharjo, K., \& Iqbal, M. (2019). The Effect of Financial Literacy and Financial Inclusion on Small Enterprises Performance in East Kalimantan. Jurnal Economia.

Sari, N. P. (2020). Pengaruh Modal Intelektual Terhadap Kinerja Bisnis Pada Ukm Di Kabupaten Sidoarjo ( Studi Empiris Pada Ukm Di Bidang Industri ). Jurnal Akuntansi Unesa.

Sugiyono, P. D. (2016a). Metode Penelitian Kuantitatif, Kualitatif, dan $R \& D$. 
Nominal: Barometer Riset Akuntansi dan Manajemen

P-ISSN: 2303-2065 E-ISSN: 2502-5430

Volume 10 No 1 (2021)

Bandung: Alfabeta.

Sugiyono, P. D. (2016b). Statistika untuk Penelitian. Bandung: Alfabeta.

Timur, D. K. dan U. P. J. (2019). Laporan Kinerja Tahun 2018. In Dinas Koperasi dan UKM Provinsi Jawa Timur (Vol. 53).

Wickham, P. A. (2006). Strategic Entrepreneurship, 4th Edition.

Wise, S. (2013). The Impact of Financial Literacy on New Venture Survival. 8(23), 30-39.

Yanti, W. I. P. (2019). Pengaruh Inklusi Keuangan Dan Literasi Keuangan Terhadap Kinerja UMKM di Kecamatan Moyo Utara. 2(1). 